\title{
İç Hastalıkları Hemşireliği Dersi Klinik Uygulamasında Öğrencilerin Hazırladıkları Bakım Planlarının İncelenmesi
}

\author{
Sevda EFIL*
}

$\ddot{O} z$

Amaç: $\mathrm{Bu}$ çalışma, İç Hastalıkları Hemşireliği dersi klinik uygulamasında öğrencilerin hazırladıkları bakım planlarının incelenmesi amacıyla yapılmıştır.

Yöntem: Tanımlayıcı tipte olan araştırmanın evrenini bir Sağlık Bilimleri Yüksekokulunda İç Hastalıkları Hemşireliği dersini alan öğrencilerin hazırladığı 320 bakım planı oluşturmaktadır. Örneklemi ise, çalışmaya dâhil edilme kriterlerine uyan 182 bakım planı oluşturmuştur. Veriler “2015-2017 Kuzey Amerika Hemşirelik Tanıları Birliği (NANDA)”, “İç Hastalıkları Hemşireliği Uygulama Öğrenci Eğitim Modülü” ve “İç Hastalıkları Hemşireliği Dersi Bakım Planı Değerlendirme Kriterleri Formu" kullanılarak toplanmıştır.

Bulgular: 13 NANDA alanından 10’nuna yönelik en az bir tane olmak üzere toplam 52 hemşirelik tanısının belirlendiği saptanmıştır. İlk üç sırada belirlenen hemşirelik tanılarının "aktivite intoleransı", “akut ağrı" ve "uyku örüntüsünde bozulma” olduğu bulunmuştur. Öğrencilerin hemşirelik süreci aşamalarını uygulama durumlarına bakıldığında; tanımlayıcı özellik, ilişkili faktörler, sonuç belirleme ve planlama aşamalarında yeterli olanların daha yüksek olduğu görülmüştür.

Sonuç: Fizyolojik sorunlara yönelik bakım planı hazırlamada yeterli olan öğrencilerin çoğunlukta olduğu görülürken, en çok değerlendirme aşamasında sorun yaşadıkları belirlenmiştir.

Özgün Araştırma Makalesi (Original Research Article)

Geliş / Received: 05.06.2020 \& Kabul / Accepted: 30.11 .2020

DOI: https://doi.org/10.38079/igusabder.748592

${ }^{*}$ Dr. Öğr. Üyesi, Çanakkale Onsekiz Mart Üniversitesi, Sağllk Bilimleri Fakültesi, İç Hastalıkları Hemşireliği Anabilim Dalı, Çanakkale, Türkiye. E-posta: sevda efil@hotmail.com

ORCID https://orcid.org/o000-0002-4988-3743 
Anahtar Kelimeler: Hemşirelik öğrencileri, hemşirelik süreci, bakım planı, hemşirelik tanıları.

\section{Analysis of Care Plans Prepared by Students in the Clinical Practice of Course of Internal Medicine Nursing}

Aim: This study seeks to analyse the care plans prepared by the nursing students in the clinical practice of the course of Internal Medicine Nursing.

Methods: The population of this descriptive study consists of 320 course plans prepared by the students attending the course of Internal Medicine Nursing at a health college. The sample of the study consists of 182 care plans, which met the inclusion criteria of the study. The data were obtained through the "Evaluation Criteria Form for Internal Medicine Nursing Care Plans", "the 2015-2017 North American Nursing Diagnosis Association", and "the Student Training Module for the Practice of Internal Medicine Nursing”.

Results: The study concluded that a total of 52 nursing diagnoses, including at least one for each area, for 10 out of 13 NANDA areas were made by the students. The top three nursing diagnoses were "activity intolerance", "acute pain" and "disrupted sleep patterns." The study also determined the nursing process phases performed by the students and found that majority of the students were competent in the phases of descriptive characteristics, associated factors, outcome determination, and planning.

Conclusion: The study revealed that the students competent in preparing a care plan for physiological problems were in majority and that the students had the most problems in the evaluation phase.

Keywords: Nursing students, nursing process, care plan, nursing diagnosis.

\section{Giriş}

Hemşirelik eğitimi, mesleki bilgiye, eleştirel düşünme ve karar verme yeteneklerine sahip profesyonel hemşire yetiştirmek için gerekli olan teorik bilgi ve uygulamaları içerir ${ }^{1,2}$. Etkili hemşirelik bakımının gerçekleşmesi için hemşirelik eğitimi ve uygulama alanında bilimsel temele dayalı hemşirelik yaklaşımı sergilenmelidir3. Bu amaçla sistematik, bilimsel bir sorun çözümleme yöntemi olan hemşirelik süreci; teorik bilgiyi uygulamaya aktarmada, doğru ve güvenilir bir şekilde sağlık sorunlarının tespit edilerek kaliteli bakımın sunulmasında en önemli araçlardan biridir4,5. 
Hemşirelik sürecinin uygulanmasına ilişkin bakım planları hemşirelik eğitiminin vazgeçilmez bir parçasıdır ${ }^{1,4}$. Klinik deneyimler sırasında hemşirelik bakımı planlarının geliştirilmesi ve uygulanması öğrencilerin etkili hemşirelik bakımı sağlama becerilerini geliştirmelerine katkı sağlar 6 . Bu nedenle öğrencilerin dinamik yaklaşım gerektiren birbiri ile bağlantılı hemşirelik süreci aşamalarını istendiği şekilde uygulayabilmeleri beklenir ${ }^{7-9}$. Fakat bu aşamaların uygulanması öğrenciler tarafından sıklıkla yanlış anlaşıldığı veya zaman kaybı olarak görüldüğü için sürece ilişkin tüm aşamalarda zorluk yaşayabilmektelerdir ${ }^{10-13}$.

Bakımın kalitesini arttırmada bakım planlarının önemi düşünüldügünnde, geleceğin hemşireleri olan öğrencilerin hemşirelik süreci aşamalarında zorluk yaşamaları endişe vericidir. $\mathrm{Bu}$ nedenle öğrencilere gerekli mesleki bilgi ve becerinin kazandırılması önemini korumaktadır. İç Hastalıkları Hemşireliği dersi, sağlığın korunması, bireyin fiziksel ve psikososyal sorunlarının tanımlanması, nedenlerinin açıklanması, kanıta dayalı hemşirelik girişimlerinin öğrenilmesi ve hemşirelik bakımı sonuçlarını değerlendirebilmesine yönelik öğrencilere önemli katkılar sağlamaktadır. Bu dersi alan öğrencilerin hemşirelik bakımını holistik bir yaklaşımla yerine getirebilmeleri için hemşirelik sürecinin aşamalarını uygulayabilme durumları değerlendirilmelidir. Literatürde, genellikle veri toplama ve hemşirelik tanılarını belirleme aşamalarının değerlendirildiği çalışmalar görülürken ${ }^{14,15}$, çok az sayıda çalışmada öğrencilerin hemşirelik sürecinin tüm aşamalarını kullanmalarına ilişkin değerlendirme yapılmıştır3,5,16,17. Aynı zamanda bu konu ile ilgili İç Hastalıkları Hemşireliği dersine ilişkin çalışma bulunmamaktadır. Bu nedenle, literatürdeki bu boşluktan yola çıkılarak İç Hastalıkları Hemşireliği dersi kapsamında öğrencilerin hazırladıkları bakım planlarının incelenmesi, hemşirelik süreci aşamalarını uygulayabilme durumlarının belirlenmesi amaçlanmıştır.

\section{Gereç ve Yöntem}

Araştırmanın Tasarımı: Tanımlayıcı bir araştırmadır.

Araştırmanın Evren ve Örneklemi: Araştırmanın evrenini bir Sağlık Bilimleri Yüksekokulunda İç Hastalıkları Hemşireliği dersini alan öğrencilerin hazırladığı 320 bakım planı oluşturmuştur. Dahiliye servisi (dahiliye, gastroenteroloji, onkoloji, enfeksiyon, kardiyoloji, göğüs, nöroloji, fizik tedavi) ve yoğun bakım ünitesinde (anestezi 
ve reanimasyon, koroner yoğun bakım) tedavi alan hastalar için hazırlanmış olan, eğitici veya rehber hemşireye sunularak tartışılan, ikinci rotasyonda hazırlanan ve dönem sonu teslim edilen 182 bakım planı çalışmaya dahil edilmiştir. Cerrahi serviste (cerrahi, kadın doğum, kalp damar cerrahi, kulak burun boğaz, göz, ortopedi, organ nakli) tedavi alan hastalar için hazırlanmış olan, birinci rotasyonda hazırlanan, dönem sonu teslim edilmeyen, sorumlu eğitici veya rehber hemşireye sunulmamış olan bakım planları çalışmaya dâhil edilmemiştir.

Verilerin Toplanması: Çalışmaya dâhil edilme kriterlerine uyan bakım planları 1-31 Aralık 2018 tarihleri arasında incelenmiştir. Dersin uygulamasına haftada bir gün bir devlet veya üniversite hastanesinde çıkılmıştır. Dönem boyunca iki rotasyon olacak şekilde uygulamaya çıkılmış olup, her rotasyonda toplam 10 grup (140 öğrenci) yer almıştır. Acil servis, diyabet polikliniği, kan alma ünitesi, solunum fonksiyon testi birimi gibi yerlere uygulamaya giden öğrencilerden ise (her rotasyonda ortalama 20 öğrenci) sadece rapor talep edilmiştir. Yataklı sağlık hizmeti veren kliniklerde uygulamaya çıkan öğrencilerden her rotasyon için alınan bakım planı sayısı "bir" ile "iki” arasında değişmekte olup, toplanan bakım planı ilk rotasyonda 120, ikinci rotasyonda 200 adettir. Öğrencilerin sağlığı değerlendirme girişimleri ve hemşirelik süreci aşamalarını uygulama durumları sorumlu eğitici veya rehber hemşireler tarafından takip edilmiştir. Bu nedenle öğrencilerin bakım planlarını kontrol etme imkanı bulunmuştur. Her öğrenci ile en az bir kez hasta başı viziti ve vaka tartışması yapılmıştır. Bununla birlikte sınıf ortamında, anlatılan konu sırasına uygun olacak şekilde vaka örnekleri sunularak tartışılmıştır.

\section{Araştırma Soruları}

1. Hemşirelik öğrencilerinin öğrenci eğitim modülüne göre veri toplama aşamasında yaptıkları sağlı̆̆ı değerlendirme girişimleri nelerdir?

2. Hemşirelik öğrencilerinin bakım planlarında 2015-2017 “Kuzey Amerika Hemşirelik Tanıları Birliği (North American Nursing Diagnosis Association, NANDA)" sınıflandırması doğrultusunda belirledikleri hemşirelik tanıları nelerdir?

3. Hemşirelik öğrencilerinin bakım planlarında en sık belirledikleri hemşirelik tanılarına göre hemşirelik süreci aşamalarını uygulama durumları nasıldır? 


\section{Verilerin Değerlendirilmesi}

Sağlı̆̆ı değerlendirme girişimleri: Öğrencilerin veri toplama aşaması için kullandıkları "İç Hastalıkları Hemşireliği Uygulama Öğrenci Eğitim Modülü" doğrultusunda öğrencilerin sağlığı değerlendirme girişimleri incelenmiştir ${ }^{18}$. Öğrenciler, bu modüle göre sağlı̆̆ değerlendirme girişimlerini tam ve doğru şekilde ifade etmişlerse "doğru”, yanlış ifade etmişlerse "yanlış” olarak yorumlanmıştır.

Hemşirelik süreci aşamalarını uygulama durumları: Öğrencilerin belirledikleri hemşirelik tanıları 2015-2017 NANDA'ya göre incelenerek sınıflandırılmıştır'19. Aynı zamanda araştırmacı tarafından kaynaklar doğrultusunda hazırlanan "İç Hastalıkları Hemşireliği Dersi Bakım Planı Değerlendirme Kriterleri Formu” ile öğrencilerin hemşirelik sürecinin her bir aşamasını uygulama durumları değerlendirilmiştir ${ }^{1,3-5,10-}$ 12,14,15,18-20. Bu formda yer alan kriterler;

$\checkmark$ Veri toplama aşaması: Bireyin mevcut veya olası durumu (soy geçmiş, özgeçmiş, şimdiki sağlık hikâyesi, belirti ve bulgular) ele alınmış mı?

$\checkmark$ Hemşirelik tanısını belirleme: 2015-2017 NANDA tanılarına uygun (bireye özgü tanımlayıcı özelliklerin dikkate alınma durumu) belirlenmiş mi?

$\checkmark$ İlişkili faktörleri belirleme: Hemşirelik sorunu ve tıbbi tanı göz önünde bulundurulmuş mu?

$\checkmark$ Beklenen hasta sonuçları belirleme: Hastanın tanımlayıcı özellikleri, sonuca ulaşmayı etkileyebilecek hasta özellikleri dikkate alınmış mı?

$\checkmark$ Hemşirelik girişimlerini planlama: Bireyin var olan durumu göz önünde bulundurularak kısa ve uzun vadeli hedefler saptanmış mı?

$\checkmark$ Hemşirelik girişimlerini uygulama: Hemşirelik tanısı ve amaçlara yönelik yapılan planlama doğrultusunda hemşirelik girişimleri ele alınmış mı?

$\checkmark$ Hemşirelik girişimlerini değerlendirme: Beklenen sonuçları ortaya koyacak ölçütlere bakılmış mı?

Veri toplama araçları doğrultusunda bu kriterler dikkate alınarak; her bir aşamayı doğru şekilde ifade edenler "yeterli”, eksikleri olanlar "kısmen yeterli”, yanlış ifade edenler ise “yetersiz” olarak yorumlanmıştır. 


\section{Araştırmanın Etik Boyutu}

Araştırma için Klinik Araştırmaları Etik Kurulu'ndan etik izin (28.11.2018 tarih ve 201821 nolu karar) alınmıştır.

\section{Verilerin Analizi}

Verilerin incelenmesinde "Statistical Package for Social Science 20.0 paket programı" kullanılmış olup, tanımlayıcı istatistiksel analizlerden (frekans, yüzde) yararlanılmıştır.

\section{Bulgular}

Öğrencilerin veri toplama aşamasında \%10’un altında $(\mathrm{n}<25)$ yaptıkları sağlı̆̆ değerlendirme girişimleri tabloda yer almamaktadır. Öğrencilerin doğru yapma oranlarının çoğunlukla yüksek olduğu, başta oral mukozayı değerlendirmek olmak üzere 1. ve 9. maddeleri daha fazla yaptıkları görülmektedir (Tablo 1).

Tablo 1. Öğrencilerin Veri Toplama Aşamasında Yaptıkları Sağlı̆̆ı Değerlendirme Girişimleri

\begin{tabular}{|c|c|c|c|c|c|}
\hline \multirow[t]{2}{*}{ Girişimler } & \multirow[b]{2}{*}{$\mathbf{n}$} & \multicolumn{2}{|c|}{ Doğru } & \multicolumn{2}{|c|}{ Yanliş } \\
\hline & & $\mathbf{n}$ & $\%$ & $\mathbf{n}$ & $\%$ \\
\hline 1. Oral mukozayı değerlendirme & 165 & 165 & 100,0 & - & - \\
\hline $\begin{array}{l}\text { 2. Günlük yaşam aktivitelerini gerçekleştirmede bağımlılık düzeyini } \\
\text { değerlendirme }\end{array}$ & 170 & 162 & 95,3 & 8 & 4,7 \\
\hline 3. Tedavi, takip ve izlem & 172 & 151 & 87,8 & 21 & 12,2 \\
\hline 4. Laboratuvar bulgularını değerlendirme & 162 & 149 & 91,98 & 13 & 8,02 \\
\hline 5. Ödemi değerlendirme & 145 & 144 & 99,3 & 1 & 0,7 \\
\hline 6. Saturasyonu değerlendirme & 173 & 139 & 80,35 & 34 & 19,65 \\
\hline 7. Beden Kitle İndeksini hesaplama & 136 & 136 & 100,0 & - & - \\
\hline 8. Solunum paternini değerlendirme & 167 & 125 & 74,85 & 42 & 25,15 \\
\hline 9. Kapiller geri dolumu değerlendirme & 108 & 102 & 94,44 & 6 & 5,56 \\
\hline 10. Tanımlayıcı özellikleri belirleme & 166 & 94 & 56,63 & 72 & 43,37 \\
\hline 11. Yaşam bulgularını değerlendirme & 173 & 87 & 50,3 & 86 & 49,7 \\
\hline 12. Şimdiki sağlık hikâyesini alma & 143 & 86 & 60,14 & 57 & 39,86 \\
\hline
\end{tabular}




\begin{tabular}{|l|c|c|c|c|c|}
\hline 13. Barsak seslerini dinleme & 75 & 75 & 100,0 & - & - \\
\hline 14. Glaskow koma skalasını değerlendirme & 78 & 73 & 93,6 & 5 & 6,4 \\
\hline 15. Basınç yarasını değerlendirme & 62 & 60 & 96,8 & 2 & 3,2 \\
\hline 16. Nabız dolgunluğunu değerlendirme & 83 & 57 & 68,68 & 26 & 31,32 \\
\hline 17. Kalp sesini dinleme & 25 & 24 & 96,0 & 1 & 4,0 \\
\hline 18. Akciğer sesini dinleme & 25 & 24 & 96,0 & 1 & 4,0 \\
\hline
\end{tabular}

Öğrencilerinin 2015-2017 NANDA sınıflamasına göre rol ilişkileri (alan 7), yaşam ilkeleri (alan 10) ve büyüme/gelişme (alan 13) alanları dışında diğer tüm alanlara ilişkin hemşirelik tanılarından en az bir ve toplam 52 farklı hemşirelik tanısı belirledikleri saptanmıştır. İlk üç sırada belirlenen hemşirelik tanılarına bakıldığında; aktivite intoleransı $(\% 65,4)$, akut ağrı $(\% 54,9)$, uyku örüntüsünde bozulma $(\% 51,6)$ olduğu tespit edilmiştir (Tablo 2).

Tablo 2: Öğrencilerin NANDA Sınıflandırmasına Göre Belirledikleri Hemşirelik Tanıları

\begin{tabular}{|c|c|c|c|}
\hline Alan/Sinıf & Hemşirelik Tanısı & $\mathbf{n}$ & $\%$ \\
\hline $\begin{array}{l}\text { Alan 1: Sağlığın geliştirilmesi } \\
\text { Sınıf 2: Sağlığın Yönetimi }\end{array}$ & Etkisiz Sağlık Yönetimi & 20 & 11,0 \\
\hline \multirow{4}{*}{$\begin{array}{l}\text { Alan 2: Beslenme } \\
\text { Sinıf 1: Besin Alımı }\end{array}$} & Beden Gereksiniminden Az Beslenme & 41 & 22,5 \\
\hline & Fazla Kilo & 20 & 11,0 \\
\hline & Yutmada Bozulma & 5 & 2,7 \\
\hline & Obezite & 3 & 1,6 \\
\hline Alan 2 / Sinıf 4: Metabolizma & $\begin{array}{l}\text { Kan Şekeri Seviyesinde Dalgalanma } \\
\text { Riski }\end{array}$ & 23 & 12,6 \\
\hline \multirow{5}{*}{ Alan 2 / Sinıf 5: Hidrasyon } & Sıvı Volüm Eksikliği Riski & 1 & 0,5 \\
\hline & Sıvı Volüm Eksikliği & 6 & 3,3 \\
\hline & Sıvı Volüm Dengesizliği Riski & 8 & 4,4 \\
\hline & Elektrolit Dengesizliği Riski & 14 & 7,7 \\
\hline & Sıvı Volüm Fazlalığı & 51 & 28,0 \\
\hline Alan 3: Boşaltım ve Gaz Değişimi & Bozulmuş Üriner Boşaltım & 12 & 6,6 \\
\hline
\end{tabular}




\begin{tabular}{|c|c|c|c|}
\hline Sinıf 1: Üriner Fonksiyon & Fonksiyonel Üriner İnkontinans & 2 & 1,1 \\
\hline \multirow{3}{*}{$\begin{array}{l}\text { Alan } 3 \text { / Sinıf 2: Gastrointestinal } \\
\text { Fonksiyon }\end{array}$} & Konstipasyon & 49 & 26,9 \\
\hline & Diyare & 5 & 2,7 \\
\hline & Gastrointestinal Motilitede Bozulma & 3 & 1,6 \\
\hline Alan 3 / Sinıf 4: Solunum Fonksiyonu & Gaz Değişiminde Bozulma & 31 & 17,0 \\
\hline $\begin{array}{l}\text { Alan 4: Aktivite-Dinlenme / Sinıf 1: } \\
\text { Uyku/Dinlenme }\end{array}$ & Uyku Örüntüsünde Bozulma & 94 & 51,6 \\
\hline \multirow{2}{*}{ Alan 4 / Sinıf 2: Aktivite/Egzersiz } & Fiziksel Mobilitede Bozulma & 27 & 14,8 \\
\hline & Yürümede Bozulma & 2 & 1,1 \\
\hline Alan 4 / Sinıf 3: Enerji Dengesi & Yorgunluk & 86 & 47,3 \\
\hline \multirow{5}{*}{$\begin{array}{l}\text { Alan } 4 \text { / Sinıf 4: Kardiyovasküler / } \\
\text { Pulmoner Yanıtlar }\end{array}$} & Aktivite İntoleransı & 119 & 65,4 \\
\hline & Etkisiz Solunum Örüntüsü & 70 & 38,5 \\
\hline & Kardiyak Debide Azalma & 46 & 25,3 \\
\hline & $\begin{array}{l}\text { Etkisiz Serebral Doku Perfüzyonu } \\
\text { Riski }\end{array}$ & 16 & 8,8 \\
\hline & Etkisiz Periferal Doku Perfüzyonu & 6 & 3,3 \\
\hline Alan 4 / Sınıf 5: Öz Bakım & Öz Bakım Eksikliği & 44 & 24,2 \\
\hline \multirow{2}{*}{$\begin{array}{l}\text { Alan 5: Algılama/Kavrama } \\
\text { Sınıf 4: Bilişsel }\end{array}$} & Bilgi Eksikliği & 30 & 16,5 \\
\hline & Hafizada Bozulma & 3 & 1,6 \\
\hline Alan 5 /Sınıf 5: İletişim & Sözel İletişimde Bozulma & 8 & 4,4 \\
\hline $\begin{array}{l}\text { Alan 6: Kendini Alglama/Sınıf 3:Beden } \\
\text { İmajı }\end{array}$ & Beden İmajinda Bozulma & 1 & 0,5 \\
\hline Alan 8: Cinsellik / Sınıf 2: Cinsel İşlev & Cinsel İşlevde Bozulma & 1 & 0,5 \\
\hline \multirow{5}{*}{$\begin{array}{l}\text { Alan 9: Baş etme/Stres toleransı } \\
\text { Sınıf 2: Başetme Yanıtları }\end{array}$} & Anksiyete & 21 & 11,5 \\
\hline & Ölüm Anksiyetesi & 4 & 2,2 \\
\hline & Etkisiz Başetme & 1 & 0,5 \\
\hline & Etkisiz İnkâr & 1 & 0,5 \\
\hline & Korku & 1 & 0,5 \\
\hline \multirow{5}{*}{$\begin{array}{l}\text { Alan 11: Güvenlik/Koruma/Sınıf 1: } \\
\text { Enfeksiyon }\end{array}$} & Enfeksiyon Riski & 73 & 40,1 \\
\hline & Kanama Riski & 75 & 41,2 \\
\hline & Düşme Riski & 74 & 40,7 \\
\hline & Oral Mukoz Membranda Bozulma & 61 & 33,5 \\
\hline & Deri Bütünlüğünde Bozulma Riski & 42 & 23,1 \\
\hline
\end{tabular}




\begin{tabular}{|l|l|l|l|}
\hline \multirow{4}{*}{} & Deri Bütünlüğünde Bozulma & 25 & 13,7 \\
\cline { 2 - 4 } & $\begin{array}{l}\text { Oral Mukoz Membranda Bozulma } \\
\text { Riski }\end{array}$ & 23 & 12,6 \\
\cline { 2 - 4 } & Aspirasyon Riski & 14 & 7,7 \\
\cline { 2 - 4 } & Doku Bütünlüğünde Bozulma & 8 & 4,4 \\
\hline Alan 11/Sınıf 6: Termoregülasyon & Hipertermi & 1 & 0,5 \\
\hline \multirow{2}{*}{ Alan 12: Konfor } & Akut Ağrı & 100 & 54,9 \\
\cline { 2 - 4 } Sinıf 1: Fiziksel Konfor & Bulantı & 10 & 5,5 \\
\hline \multirow{2}{*}{ Alan 12/Sınıf 3: Sosyal Konfor } & Konforda Bozulma & 3 & 1,6 \\
\cline { 2 - 4 } & Yalnızlık Riski & $\mathbf{2}$ & $\mathbf{1 , 1}$ \\
\cline { 2 - 4 } & Sosyal İzolasyon & $\mathbf{2}$ & $\mathbf{1 , 1}$ \\
\hline
\end{tabular}

Öğrencilerin belirledikleri hemşirelik tanılarına göre hemşirelik süreci aşamalarını uygulama durumlarına bakıldığında; tanımlayıcı özellikleri belirleme, ilişkili faktörleri saptama, sonuç belirleme ve planlama aşamalarının yeterli olanların daha fazla olduğu görülmektedir. Uygulama aşamasında kısmen yeterli olanların daha fazla olduğu görülürken, değerlendirme aşamasında yeterli olanların düşük oranda olduğu belirlenmiştir (Tablo 3). 


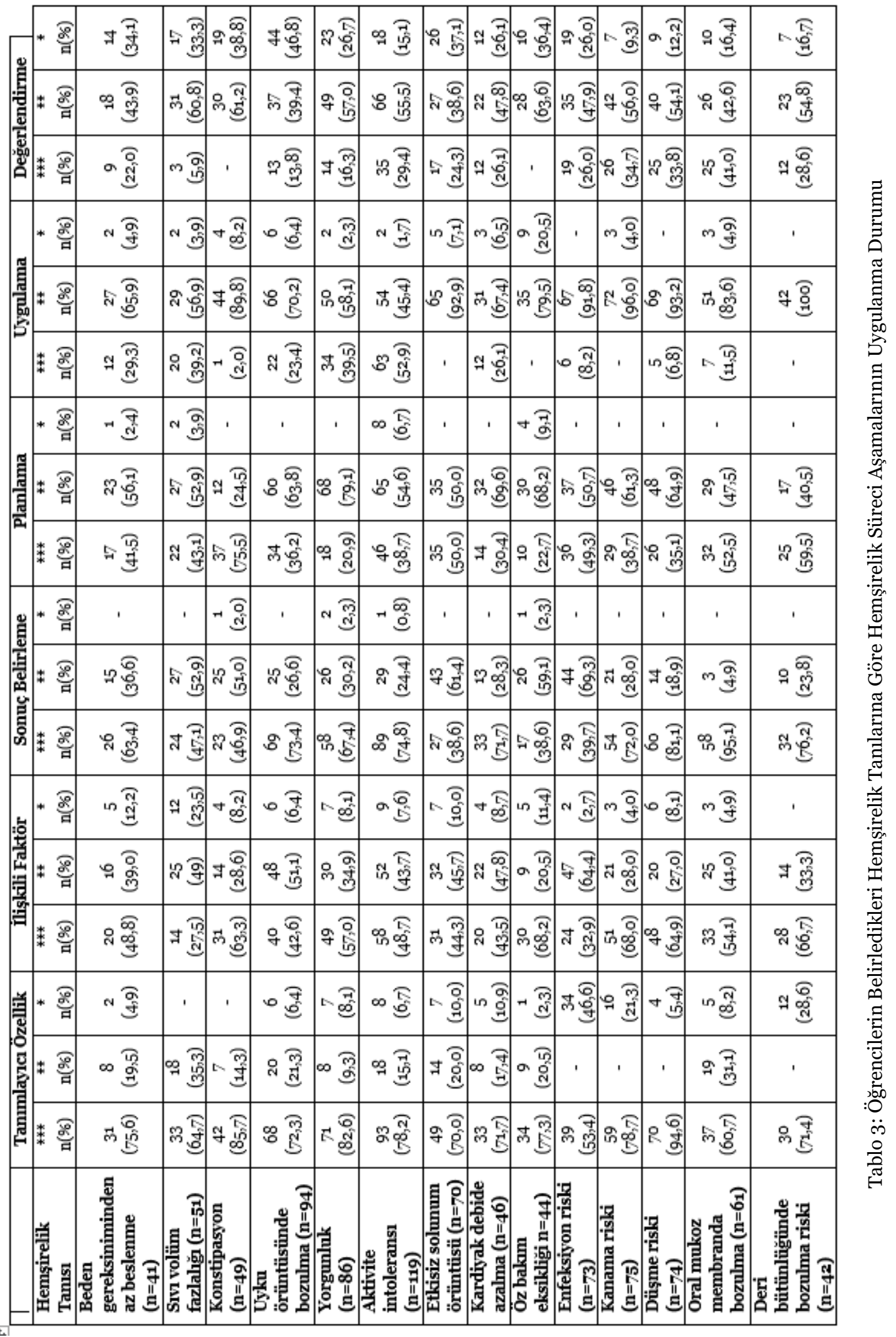




\section{Tartışma}

Bakım planları hemşirelik bakımının bilimsel temellere dayandırılmasında önemli bir $\operatorname{araçtır}^{17,21}$. Öğrencilikten profesyonelliğe geçiş sürecinde, bakım planlarının kullanımına ilişkin yeterli bilgi ve beceri kazanılmasının kaliteli hemşirelik bakımı sunumunda önemli olduğu bilinmektedir ${ }^{20,22}$. Bu nedenle çalışmada, İç Hastalıkları Hemşireliği dersini alan öğrencilerin hazırladıkları bakım planları incelenerek hemşirelik süreci aşamalarını uygulama durumları değerlendirilmiştir.

Hemşirelik bakımı öncesi bireyin sağlı̆̆ı sistematik ve kapsamlı bir şekilde değerlendirilmelidir ${ }^{1,20,23}$. Bu aşama karar verme sürecine yön vermeyi sağladığı gibi hemşirelik sürecinin diğer aşamalarının da doğru bir şekilde uygulanmasında önemli bir adımdır 8 ,24. Çalışmada öğrenciler veri toplama aşamasında çoğunlukla fizyolojik sorunlara yönelik değerlendirme yapmışlardır (Tablo 1). Çalışmanın bulguları ile benzer şekilde vaka tartışmaları yapan ${ }^{5,9,25,26}$ veya simüle hasta ile eğitim alan ${ }^{20}$ öğrencilerinde fizyolojik sorunları daha fazla ele aldıkları görülmektedir. $\mathrm{Bu}$ durum öğrencilerin psikolojik ve sosyal boyutlarda sorunların saptanmasında yetersiz olduklarını gösterdiği gibi bu sorunlara yönelik problem çözmelerinin de güç olacağını düşündürmektedir. Bu nedenle veri toplamanın holistik yaklaşımı sergileyebilecek şekilde yapılmasının üzerinde durulması gereken bir konu olduğu düşünülmektedir.

Hemşirelik tanısının belirlenmesi, hemşirelik bakımı sürecine rehberlik etmek için toplanan tüm verilerin sentezine dayanır ${ }^{26}$. Doğru hemşirelik tanısının belirlenmesi diğer aşamaların doğru yönlendirilmesine rehberlik sağladığı gibi ${ }^{1,5}$ kaliteli bakım sunma fırsatı da sağlamaktadır ${ }^{20,22}$. Literatürde öğrencilerin tıbbi tanılara daha fazla odaklanmaları nedeni ile hemşirelik tanılarını belirlerken zorlandıkları belirtilmiştir111,12,14. Literatürün aksine öğrencilerin güncel NANDA tanıları doğrultusunda hemşirelik tanılarını belirleyebilmeleri bu konuda güçlük yaşamadıklarını göstermektedir. Pieper ve ark. (2017) birinci sınıf hemşirelik öğrencilerinin akut ve kronik yarası olan sekiz hastaya yönelik yaptıkları bakım planlarını incelediklerinde, en sık belirlenen hemşirelik tanılarının fiziksel harekette bozulma, aktivite intoleransı, deri bütünlüğünde bozulma, konforda bozulma, dengesiz beslenme ve enfeksiyon riski olduğunu saptamışlardır ${ }^{6}$. Birinci sınıf hemşirelik öğrencilerinin belirledikleri hemşirelik tanılarının incelendiği bir çalışmada en çok güvenlik/koruma, aktivite/dinlenme, konfor, eliminasyon ve beslenme alanlarına 
yönelik tanıların kullanıldığı tespit edilmiştir ${ }^{25}$. Son yapılan çalışmalarda öğrencilerin ${ }^{6,9}$ ve hemşirelerin ${ }^{27}$ "uyku örüntüsünde bozulma" tanısını daha az sıklıkta belirledikleri ya da hiç saptamadıkları dikkat çekmektedir. Literatürün aksine, öğrencilerin uyku örüntüsünde bozulmayı daha fazla belirlemiş olmalarının fizyolojik sorunların (ağrı, dispne gibi) neden olabileceği hemşirelik sorunlarına dikkat etmelerinden kaynaklanmış olabilir. Bu bağlamda öğrencilerin, hastaların yaşam kalitesini olumsuz etkileyebilecek uyku sorununun farkında olmaları umut vericidir. Çalışmada öğrencilerin sıklıkla belirledikleri hemşirelik tanılarının fizyolojik sorunlara yönelik olduğu, cinsellik, rol ilişkileri gibi alanlara yönelik sorun belirleyemedikleri görülmektedir. $\mathrm{Bu}$ durumun literatürde de ifade edildiği gibi soyut ve mahremiyeti etkileyen durumların tespit edilmesinde güçlük yaşanılmasi ${ }^{9,10}$ ve bu alanlara yönelik soru sormaya çekinilmesinden kaynaklandığ $1^{17,28}$ düşünülmektedir. Aynı zamanda haftada bir gün uygulamaya çıkılması hastayı tüm yönleri ile ele almayı kısıtlamış olabilir. Bu nedenle öğrencilerin bu alanlara yönelik nasıl veri toplayacaklarını bilmeleri konusunda rehberlik sağlanması önemlidir.

Literatürde hemşirelik öğrencilerinin subjektif ve objektif verileri saptayabilme, güvenilir ve doğru veriler ışığında ilişkili faktörleri ortaya koyabilmede7,8,11,14 ve hastaların ihtiyaçlarının hemşirelik tanıları olarak kabul edilmesinde zorluk yaşadıkları ifade edilmiştir. ${ }^{10-12,15}$ Literatürün aksine çalışmada belirlenen hemşirelik tanılarına ilişkin; öğrencilerin tanımlayıcı özellik, ilişkili faktör, sonuç belirleme ve planlama aşamalarında çoğunlukla yeterli oldukları belirlenmiştir (Tablo 3). Bu sonuçlar bireye özgü tanımlayıcı özellikler dikkate alınarak hemşirelik tanılarının belirlendiğini, NANDA'nın kullanıldığını, hemşirelik sorunu ve tıbbi tanı göz önünde bulundurularak ilişkili faktörlerin saptandığını göstermektedir. Sonuca ulaşmayı etkileyebilecek hasta özellikleri dikkate alınarak amaçların belirlenmesinin, bireye özgü kısa ve uzun vadeli hedeflerin planlanabilmesinin vaka tartışmalarının olumlu yansıması olduğu düşünülmektedir. Aynı zamanda öğrencilerin klinik uygulamada danışabilecekleri eğiticilere ulaşma imkânlarının olmasından da kaynaklanmış olabilir.

Çalışmada uygulama aşamasının kısmen yeterli oranda yapılma oranı yüksektir (Tablo 3). Bu sonuç öğrencilerin uygulama aşamasını hemşirelik tanısı, amaç ve planlama doğrultusunda gerçekleştirmede eksikleri olduğunu göstermektedir. Bu bulguların aksine başka bir çalışmada, öğrencilerin hemşirelik sonuçları ve girişimlerini \%95’in üzerinde doğru ifade ettikleri belirlenmiştir. Aynı çalışmada öğrencilerin belirledikleri 
hemşirelik girişimlerinin hemşirelik tanısı ile beklenen hasta sonuçlarına yönelik ve sorunu çözümleyebilecek şekilde yeterli oldukları bulunmuştur ${ }^{15}$. Öğrencilerin hemşirelik tanısını belirleme, beklenen sonuçlara uygun hemşirelik girişimlerini planlama ve problem çözmede orta düzeyde başarılı olduklarını ortaya koyan çalışmalarda bulunmaktadır ${ }^{1,10,29}$. Bu çalışmaların aksine Yılmaz ve ark. (2015) çalışmasında öğrencilerin yarısından fazlasının uygulama ve değerlendirme aşamalarını açıklama konusunda yetersiz oldukları tespit edilmiştir5.

Hemşirelik süreci, problemin yeniden ortaya konması ve bakım planının tekrar gözden geçirilmesini sağlayan geribildirime odaklanır3. Bu nedenle son aşama olan değerlendirmede yetersizliklerin olması problem çözme sürecine olumsuz yansıyabilir Çalışmada diğer aşamaların aksine, değerlendirme aşamasında yeterli olanlar daha azdır (Tablo 3). Uygulamaya haftada bir gün çıkılması, uygulama ve değerlendirme aşamasını gerçekleştirebilmeleri için gerekli zamanı bulamamalarına neden olmuş olabilir. Bulguların aksine, başka bir çalışmada değerlendirme aşamasını doğru yapan öğrencilerin daha fazla olduğu saptanmıştır³. Bu farkın dördüncü sınıf hemşirelik öğrencilerinin yeterli bilgiyi kazanmalarını sağlayacak eğitim süreçleri ve klinik deneyimlerinden kaynaklandığı düşünülmektedir.

\section{Sonuç ve Öneriler}

Sonuç olarak; fizyolojik sorunlara yönelik bakım planı hazırlamada yeterli olan öğrencilerin çoğunlukta olduğu görülmektedir. Öğrencilerin psikososyal sorunları belirlemede ve değerlendirme aşamasında yetersiz oldukları belirlenmiştir. Bu bağlamda öğrencilerin bakım planı kullanımı ile ilgili bilgi düzeylerinin aralıklı olarak değerlendirilmesi ve bakım planına ilişkin bilgilerinin güncel tutulmasının önemli olduğu düşünülmektedir. Bununla birlikte bakım planlarında tüm aşamaların doğru bir şekilde yapılabilmesi için bakımda devamlılı̆̆ı sağlayacak koşullar öğrencilere sunulmalıdır. Bunun için haftada birden fazla uygulamaya çıkılması, simüle hasta laboratuvarları, standart hasta ile eğitim veya ters yüz öğrenme imkanı sağlayan dijital eğitim teknolojilerinin (edmood, edpuzzle gibi) kullanımı önerilmektedir. Öğrencilerin bakım planı hazırlama ve uygulamayı etkilediği düşünülen değişkenlerin incelendiği geniş örneklem sayıları ile yapılan çalışmalar konuya ışık tutacaktır. 


\section{Araştırmanın Sınırlılıkları}

Bu çalışmada sadece bir Sağlık Bilimleri Yüksekokulunun İç Hastalıkları Hemşireliği dersinde hazırlanan bakım planları incelendiği için sonuçlar genellenemez. Aynı zamanda öğrencilerin sınırlı klinik deneyime sahip olmaları, haftada bir gün uygulamaya çıkmaları hemşirelik süreci aşamalarının devamlılı̆̆ını sağlamalarını kısıtlamaktadır. Literatürde sürecin tüm aşamalarını değerlendiren araştırmaların az olması çalışma sonuçlarının yorumlanmasını kısıtlamaktadır.

\section{KAYNAKLAR}

1. Can G, Erol O. Nursing students' perceptions about nursing care plans: a Turkish perspective. Int J Nurs Pract. 2012;18(1):12-19. doi: 10.1111/j.1440172X.2011.01985.X

2. Marhigiano G, Eduljee N, Harvey K. Developing critical thinking skills from clinical assignments: a pilot study on nursing students' self-reported perceptions. J Nurs Manag. 2011;19(1):143-152. doi: 10.1111/j.13652834.2010.01191.x.

3. Keski Ç, Karadağ A. Hemşirelik son sınıf öğrencilerinin hemşirelik süreci hakkındaki bilgi düzeylerinin incelenmesi. Hemşirelikte Araştırma Geliştirme Dergisi. 2010;12(1):41-52.

4. Kaya N, Babada $\breve{g}$ K, Yeşiltepe Kaçar G, Uygur E. Hemşirelerin hemşirelik model/kuramlarını, hemşirelik sürecini ve sınıflama sistemlerini bilme ve uygulama durumları. Maltepe Üniversitesi Hemşirelik Bilim ve Sanatı Dergisi. 2010;3(3):24-33.

5. Yılmaz FT, Sabancıoğulları S, Aldemir K. The opinions of nursing students regarding the nursing process and their levels of proficiency in Turkey. $J$ Caring Sci. 2015;4(4):265-275. doi:10.15171/jcs.2015.027.

6. Pieper B, Monahan J, Keves-Foster MK, Farner J, Alhasanat D, Albdour M. A quality improvement project: what first-year nursing students include in their nursing care plans for patients with acute or chronic wounds. Ostomy Wound Manage. 2017;63(10):42-47. doi:10.25270/owm.2017.4247. 
7. Aydin N, Akansel A. Determination of accuracy of nursing diagnoses used by nursing students in their nursing care plans. International Journal of Caring Sciences. 2013;6(2):252-257.

8. Tambağ H, Can R. Hemşirelik öğrencilerinin psikiyatri hemşireliği dersi uygulamalarında NANDA hemşirelik tanılarını belirleme düzeylerinin değerlendirilmesi. Yıldırım Beyazıt Üniversitesi Sağlık Bilimleri Fakültesi Hemşirelik E-Dergisi. 2014;2(3):13-20.

9. Uysal N, Arslan GG, Yılmaz İ, Alp FY. Hemşirelik ikinci sınıf öğrencilerinin bakım planlarındaki hemşirelik tanıları ve verilerin analizi. Celal Bayar Üniversitesi Sağlık Bilimleri Enstitüsü Dergisi. 2016;2(5):139-143.

10. Özer FG, Kuzu N. Öğrencilerin bakım planlarında hemşirelik süreci ve NANDA tanılarını kullanma durumu. Ege Üniversitesi Hemşirelik Yüksekokulu Dergisi. 2006;22(1):69-80.

11. Güner P, Terakye G. Hemşirelik yüksekokulları son sınıf öğrencilerinin hemşirelik tanılarını belirleyebilme düzeyleri. Cumhuriyet Üniversitesi Hemşirelik Yüksekokulu Dergisi. 2000;4(1):9-15.

12. Yönt GH, Khorshid L, Eşer I. Examination of nursing diagnoses used by nursing students and their opinions about nursing diagnoses. International Journal of Nursing Terminologies and Classification. 2009;20(4):162-168. doi: 10.1111/j.1744-618X.2009.01131.X.

13. Andsoy II, Güngör T, Dikmen Y, Nabel E. Hemşirelerin bakım planını kullanırken yaşadıkları güçlükler. Journal of Contemporary Medicine. 2013;3(2):88-94.

14. Erden S, Deniz S, Arslan S, Yurtseven Ş. Hemşirelik öğrencilerinin cerrahi hastalıkları hemşireliği dersi uygulamalarında hemşirelik tanılarını belirleme düzeylerinin incelenmesi. Van Tzp Dergisi. 2018;25(2):108-112.

15. Kaya N, Kaya H, Babadağ K. Öğrencilerin hemşirelik süreci formlarının planlama aşamasının incelenmesi. İ.Ü.F.N. Hem. Derg. 2004;13(52):79-90.

16. Sezgin İ. Hemşirelik Sürecinde Farklı Eğitim Düzeyindeki Hemşire Öğrencilerin Süreci Uygulamadaki Başarılarına İlişkin Bir Çalışma. [yüksek lisans tezi]. 
İstanbul, Türkiye: Hemşirelik Esasları Anabilim Dalı, İstanbul Üniversitesi Sağlık Bilimleri Enstitüsü;1996.

17. Taşdemir G, Kızılkaya M. Sağlık yüksekokulu son sınıf öğrencilerin ruh sağllğı ve hastalıkları hemşireliği dersi klinik uygulamasında NANDA hemşirelik tanılarının incelenmesi. International Journal of Human Sciences. 2013;10(1):246-257.

18. Enç N, Can G, Özcan Ş, Tülek Z, Uysal H, Alkan HÖ. İstanbul Üniversitesi Hemşirelik Fakültesi İç Hastalıkları Hemşireliği Uygulama Öğrenci Eğitim Modülü (9-26). 1. baskı. In: Enç N, Can G. İç Hastalkkları Hemşireliği Uygulama Öğrenci Eğitim Modülü. İstanbul: Nobel Tıp Kitapevi; 2012.

19. Herdman TH, Kamitsuru S. Nursing Diagnoses, Definitions and Classification 2015-2017. In: Herdman TH. Third edition: The NANDA international nursing diagnoses. International considerations on the use of the NANDA-ı nursing diagnoses. Oxford: Wiley Blackwell; 2014.

20. Karadag M, Calıskan N, Iseri O. Effects of case studies and simulated patients on students' nursing care plan. Int J Nurs Knowl. 2016;27(2):87-94. doi: 10.1111/2047-3095.12080.

21. Luctkar-Flude M, Wilson-Keates B, Larocque M. Evaluating high-fidelity human simulators and standardized patients in an undergraduate nursing health assessment course. Nurse Educ Today. 2012;32(4):448-452. doi:10.1016/j.nedt.2011.04.011.

22. Karaöz S. Hemşirelik eğitiminde klinik değerlendirmeye genel bakış: güçlükler ve öneriler. DEUHYO ED. 2013;6(3):149-158.

23. Junnola T, Eriksson E, Salanterä S, Lauri S. Nurses' decision-making in collecting information for the assessment of patients' nursing problems. J Clin Nurs. 2002;11(2):186-196. doi:10.1046/j.1365-2702.2002.00609.x.

24. Junttila K, Salentera S, Hupli M. Perioperative nurses' attitudes towards the use of nursing diagnoses in documentation. $J$ Adv Nurs. 2005;52(3):271-280. doi: 10.1111/j.1365-2648.2005.03586.x 
25. Türk G, Tugrul E, Sahbaz M. Determination of nursing diagnoses used by students in the first clinical practice. Int J Nurs Knowl. 2013;24(3):129-133.

26. Yönt GH, Korhan EA, Erdemir F, Müller-Staub M. Nursing diagnoses determined by first year students: a vignette study. Int J Nurs Knowl. 2014;25(1):39-42.

27. Türen S, Işık FÇ, Morgül NU, Atakoğlu R. Koroner yoğun bakımda kalp yetersizliği hastaları için belirlenen hemşirelik tanıları ve NANDA’ya Uygunluğunun Değerlendirilmesi. Journal of Cardiovascular Nursing. 2017;8(17):115-120. doi: 10.5543/khd.2017.18199

28. Efil S, Demir H, Kapıcı M, Gül E. Öğrencilerin iç hastalıkları hemşireliği dersi uygulamasında yaşadıkları sorunlar. Sağlık ve Yaşam Bilimleri Dergisi. 2019;1:1-6. https://doi.org/10.33308/2687248X.201912142

29. Karadakovan A. Yeşilbalkan ÖU. Öğrencilerin nörolojik hastalarda saptadıkları NANDA hemşirelik tanılarının incelenmesi. Atatürk Üniversitesi Hemşirelik Yüksekokul Dergisi. 2004;7(3):1-7. 